\title{
A Systematic Review of the Literature: Exploring Correlates of Sexual Assault and Homelessness
}

\author{
Lei $\mathrm{Xu}^{1^{*}}$, Victor G Aeby ${ }^{2}$, Tracy Carpenter-Aeby ${ }^{3}$, Wenhua Lu ${ }^{4}$, Laura Fisher ${ }^{2}$, Melissa Hardee $^{2}$ and Nina Rowson ${ }^{2}$ \\ ${ }^{1}$ Department of Health Education and Promotion, East Carolina University, Greenville, NC, 3205 Carol Belk Building, Greenville, NC 27858, USA \\ ${ }^{2}$ Department of Health Education and Promotion, East Carolina University, Greenville, NC, 2205 Carol Belk Building, Greenville, NC 27858, USA \\ ${ }^{3}$ School of Social Work, College of Health and Human Performance, East Carolina University, Rivers 201, Greenville, NC 27858-4353, USA \\ ${ }^{4}$ Department of Childhood Studies, Rutgers University, New Jersey, 450-7 Cooper St, Camden, New Jersey, NJ 08102, USA
}

*Corresponding author: Lei Xu, Department of Health Education and Promotion, College of Health and Human Performance, East Carolina University, 300 Curry Court, Greenville, NC 27858, USA, Tel: (252)328-1611; Fax: (251) 328-1285; E-mail: xul14@ecu.edu

Received date: April 30, 2016; Accepted date: June 20, 2016; Published date: June 27, 2016

Copyright: (c) $2016 \mathrm{Xu} \mathrm{L}$, et al. This is an open-access article distributed under the terms of the Creative Commons Attribution License, which permits unrestricted use, distribution, and reproduction in any medium, provided the original author and source are credited.

\begin{abstract}
Sexual assault is a traumatic event and the aftermath can be devastating. Victims who of sexual assault may experience comorbid issues while trying to recover from this trauma, such as homelessness. Whether the victim is trying to escape an abusive home situation or is being sexually molested while serving in the armed forces, homelessness has been observed as a trend among those impacted. The purpose of this systematic literature review (SLR) was to provide an extensive summary of the impact that sexual assault has on an individual's life and to also provide information regarding the number of articles pertaining to sexual assault and homelessness. A systematic approach was used to analyze the available literature; using keywords to help identify important articles that were pertinent to the topic. The outcome of the literature review revealed a total of 25 relevant articles relating to the key words. This literature indicated that further education is imperative for caregivers or social workers to better understand the symptoms associated with adolescent homelessness and runaway-ism, as most homeless youth will also meet the criteria for psychiatric disorders.
\end{abstract}

Keywords: Sexual assault; Homelessness; Systematic literature review; Long-lasting effect

\section{Introduction}

There are an estimated 800,000 to 2 million youth who become homeless each year in the U.S. Among these, approximately $40 \%$ will never return home [1]. Causes of runaway behavior vary depending on the individuals, reasons including, but not limited to, family conflict, escape from family violence, desire for independence and financial circumstances [2]. According to Terrell, "one in eight adolescents will run away from home prior to his or her 18th birthday. In addition, when a child is from a single-parent household or a household with eight or more persons, figures almost double" $[3]^{268}$. Studies conducted in the 1990 s estimate that $70 \%$ of homeless adolescents were physically and/or sexually abused [3]. Although not as common, some youth run away from home for the freedom and lack of structure but unfortunately they soon realize they have put themselves at an increased risk to become a victim of assault [3].

Studies have found that gay, lesbian and bisexual homeless youth experience higher rates of victimization than heterosexual youth because of the increased rates of abuse, both physical and sexual, in the home [4]. Gay, lesbian and bisexual youth also experience higher rates of family conflict and lack of support. Higher rates of abuse while living on the streets have been reported among gay, lesbian and bisexual homeless youth [4].

Homeless youth and adolescents are not the only population to experience sexual assault. On any given night, up to 300,000 women across the nation are without a home [5]. Rates of abusive history are higher among homeless persons than the general population, and are also higher among women than men [5]. A survey of the Los Angeles area found that only $4 \%$ of single men were sexually assaulted while homeless compared to $16 \%$ of single women [6].

Another population that has limited research is the homeless who are victims of military sexual assault or trauma. Female veterans report less combat exposure than their male counterparts but report higher rates of sexual assault and harassment. Female veterans are at a higher risk of homelessness when measured against non-veteran females [7]. Although majority of military sexual trauma is experienced by females, it is not completely nonexistent among men. Of the homeless population who report to the Veteran Health Administration, $39.7 \%$ of females and $3.3 \%$ of males are victims of military sexual assault [8].

Based on the research that was obtained, historically, mental illness has played a major role in sexual assault and homelessness. As of 1995 majority of the research on the development of services was based on observations of homeless mentally ill men or housed mentally ill women [9]. A lack of research has been recorded by Goodman regarding the high levels of victimization among the homeless mentally ill population, especially women. Her study sought to change that problem [9]. Since her research, there have been several additional studies on the topic of homeless women who may also have a mental illness.

Existing research regarding sexual assault and homelessness varies depending on the location and specific demographic that is being studied. Youth and adolescent populations seem to be the most 
common, followed by females who may or may not have dependents. However, research appears scarce in regards to military sexual assault in relationship to becoming homeless, as well as homelessness and sexual assault correlation among a wider variety of demographics and populations. A review of the existing literature is needed to evaluate the breadth of existing data, as well as underline gaps that must be filled. Given the astonishing prevalence of homeless individuals, it is important that professionals have at their disposal information for use in education, therapy, interventions, and advocacy for the various populations that are affected. With a more comprehensive academic description of these trends, professionals may use this data to more effectively prevent assaults and assist those already victimized.

This systematic literature review was completed by utilizing online library resources generated by East Carolina University. The variables for this literature review were defined as homelessness and sexual assault. No hypothesis is recorded, as this was an exploratory study. The purpose of this review was to provide a comprehensive report of the available research regarding the correlation of sexual assault and homelessness. The researchers were interested in the number of studies to begin to understand the scope of the problem, which was a limited amount of data available in regards to specific demographics. Articles were selected using the keywords 'sexual assault' and 'homelessness' to assess the amount of research that was available.

\section{Search Methods}

This study was completed using a systematic literature review using the guidelines in Figure 1. A systematic literature review is a carefully organized, comprehensive, and transparent studies of previous research on a particular topic [10]. This research follows written protocols that specify their central objectives, concepts, and methods in advance [10]. This review explores sexual assault and homelessness using Figures 1 and 2. A search for relevant articles was conducted by utilizing the key words 'sexual assault' and 'homelessness.' Multiple databases were searched including SocIndex with full Text; Academic Search Complete, ERIC, LGBT Life, PsycARTICLES, PsycINFO, and Women's Studies International. The search resulted in articles that ranged from 1988 to current 2015 studies (Tables 1 and 2). Dissertations, books, magazines, and articles that did not match the specified key words were then omitted from the results list. The search was also limited to peer reviewed scholarly articles. Following the systematic review shown in Figure 1 the search revealed $\mathrm{N}=25$ articles, 20 of these being within the last 10 years. Prior to the year 1989, research was extremely limited, and possibly nonexistent depending on the specific geographic location desired for study. The 20 articles consisted of only peer reviewed scholarly articles. The 25 articles were selected based on key words and relevancy to the topic studied.

In conducting a systematic literature review there are a variety of designs and measures. Of the articles revealed $(\mathrm{N}=25)$, the measures consisted of checklist, face-to-face interviews, focus group interviews, telephone interviews, registries, self-administered questionnaires, surveys, short forms, psychometric instruments, Wechsler Abbreviated Scale of Intelligence, and structured assessments. The research designs consisted of an $\mathrm{AB}$ design, case-control study, qualitative articles, national cross-sectional study, cross-sectional, observational study, multivariable logistic regression; a secondary analysis of data collected from a previous cross-sectional study, systematic review, and probability based sampling design, longitudinal diagnostic study, empirical study, and systematic sampling strategy. Articles contained a variety of participants, consisting of youth, young adults, men, and women of all races. The researchers found their participants at shelters, drug rehabilitation programs, on the street, specialized homeless veteran programs, drop-in centers, and meal locations. Most of this research took place in the U.S, but there were also articles that involved research from the United Kingdom, Canada, and Australia. During the research process, the literature that was reviewed indicated that majority of participants left home because of some type of abuse going on in the home.

1. Defining the review question and developing criteria for including studies: How many articles are in the professional literature regarding sexual assault and homeles sness?

2. Searching for studies: The following search engines were used ERIC, PsycARTICLES, Social Work Index, Academic Search Complete, LGBT Life with Full Text, PsycINFO, Women's Studies International

3. Selecting studies and collecting data: Using key words, each article was reviewed for relevance. A nominal list of articles was constructed and a total of 80 articles were evaluated. 25 articles were selected for the literature review.

4. Assessing risk of bias in included studies: A bias that was encountered was assuming that al sexual assault victims are low income, female and victimized by a male.

5. Analyzing data: Unit of Analysis is the literature review sheets that are completed for each article. $\mathrm{N}=25$

6. Addressing and reporting biases: Limiting selected articles to peer reviewed articles in a specific geographic location.

7. Presenting results and "summary of findings" tables: See Table 2.

8. Interpreting results and drawing conclusions: After analyzing and assessing the results from the systematic literature review, several

Figure 1: Cochrane systematic review.

\section{Results}

As shown in Tables 1 and 2, research studies have provided a substantial amount of information regarding the topic of homelessness and history of sexual assault. The findings of the 25 articles that were located can be organized into several bodies of information (Table 3 ). 
Research Question: How many articles are in the professional literature regarding sexual assault and homelessness?

\section{Revised Research Question}

2. Purpose: To determine if a history of sexual assault is an indicator of homelessness

3. Revised Purpose: To create an understanding of the number of articles found in the literature

4. Title: Exploring Sexual Assault and homelessness using a Systematic Literature Review

5. Variables: Homelessness and Sexual Assault

6. Attributes: 25 articles (unit of analysis)

7. Level of Measurement: ratio

8. Hypothesis: no hypothesis - exploratory study

9. Design: systematic literature review; see Figure 1

10. Is sues with Feasibility: Initial limitations on quantity of articles

11. Literature Review:

12. Outcome: $\mathrm{N}=25$

13. Level of Competency before Class: Low

14. Level of Competency after Class

15. What other information do you need to continue? Nothing, literature review is complete

Figure 2: Research question and purpose.

Eleven of the articles reviewed concerned the extent of sexual assault among homeless individuals. Washington et al. [10] found that sexual assault was a characteristic of homelessness in addition to Tsai [7], the latter also indicated that different types of sexual trauma were concurrent with different patterns of homelessness. Rew's study determined that homeless youth experienced more sexual abuse than those with a home [11]. Heslin et al. attributed lack of personal protective shelter as a cause of violence, including sexual, to the homeless [6]. Regarding sexual abuse among homeless youth, Whitbeck et al. [12] found that their lives are characterized by a high frequency of sexual trauma, and according to Tyler et al. [13] between one-third and one-half of this demographic were found to be affected since becoming homeless. In an earlier study, Tyler found that among homeless youth, lesbian, gay, or bisexual individuals were more likely to experience victimization [4]. Sundin et al. reported that sexual assault among homeless youth was more prevalent in Western countries than the projected average of the world [14]. Three articles reported the willingness of homeless abuse victims to seek help. Tyler et al. stated that women are more likely than men to report any sexual assault or abuse and those minorities are more likely to be discrepant reporters [15]. However, Maas et al. found in an earlier study that women may be reluctant, due to feelings of shame, guilt, and fear [2]. In addition, youth without a high school diploma were more likely to be interested in treatment options [1].

Eight articles made suggestions of sexual or physical abuse being predictive or causative of homelessness or running away from home in youth and women. As part of their study, Davies-Netzley et al. found $76.7 \%$ of homeless women reported abuse during childhood [16]. Studies by Maas et al., Powers et al. and Ferguson determined among homeless youth that childhood abuse and neglect, including that of a sexual nature, was a preceding occurrence in fleeing their households $[2,17,18]$. In a self-report collection, Terrell observed that one in eight youth will run away from home before their 18th birthday [3]. The data of Johnson et al. indicted that female adolescent victims of sexual assault were more likely to leave their home following abuse within the household [19]. The only study on homeless women who ran away from their households following domestic abuse was performed by Whitbeck et al. which identified two-thirds of homeless women were badly beaten or raped by their partner, and over half of these women were sexually assaulted in some form other than rape [20]. Hudson et al. additionally found of homeless women that one-third were abused as minors, either physically or sexually [21].

\begin{tabular}{|c|c|c|c|c|c|c|}
\hline Study & $\mathbf{N}$ & Activities & Research & Measures & Statistical Analysis & Outcomes \\
\hline $\begin{array}{lr}\text { Trauma } & \text { experience } \\
\text { among } & \text { Homeless } \\
\text { Female Veterans. }\end{array}$ & 1 & $\begin{array}{l}\text { Funded specialized } \\
\text { homeless veterans } \\
\text { programs. }\end{array}$ & $A B$ Design & $\begin{array}{l}{ }^{*} \text { Exposure to trauma was } \\
\text { assessed with the Life Events } \\
\text { Checklist. } \\
{ }^{*} \text { Self-reporting. }\end{array}$ & $\begin{array}{l}\text { * } \mathrm{N}=581,121 \text { reported rape, } \\
176 \text { reported sexual } \\
\text { assault during military duty. } \\
{ }^{*} \text { Descriptive statistics } \\
\text { summarized participant's } \\
\text { baseline. } \\
\text { "Linear mixed models and } \\
\text { generalized linear models } \\
\text { were conducted on follow } \\
\text { ups. }\end{array}$ & $\begin{array}{l}\text { *Different types of trauma } \\
\text { showed different patterns for } \\
\text { homelessness. } \\
\text { *Sexual assault was associated } \\
\text { with more homeless days. } 42 \% \\
\text { of participants reported sexual } \\
\text { assault while in the military. }\end{array}$ \\
\hline $\begin{array}{l}\text { Risk factors for } \\
\text { homelessness among } \\
\text { women veterans. }\end{array}$ & 2 & $\begin{array}{lr}\text { Subjects } & \text { were } \\
\text { recruited } & \text { from } \\
\text { outreach } & \text { sites } \\
\text { (shelters, } & \text { drop-in } \\
\text { centers) } & \text { and } \\
\text { referrals } & \text { from } \quad \text { VA } \\
\text { centers. } & \end{array}$ & $\begin{array}{l}\text { Case-control } \\
\text { study } \\
\text { (matched } \\
\text { case-control } \\
\text { design) }\end{array}$ & $\begin{array}{l}\text { Face to face and telephone } \\
\text { interviews were conducted. }\end{array}$ & $\begin{array}{l}\mathrm{N}=33 \text { homeless veterans } \\
\text { and } \mathrm{N}=165 \text { housed } \\
\text { veterans (age matched) } \\
{ }^{*} \text { Characteristics measured } \\
\text { by using chi-squared tests } \\
\text { and students t-test. } \\
\text { Logistics were calculated } \\
\text { using LogXact. }\end{array}$ & $\begin{array}{l}\text { Women who have served in the } \\
\text { military are three to four times } \\
\text { more likely to become } \\
\text { homeless than non-veteran } \\
\text { women. }\end{array}$ \\
\hline
\end{tabular}


Citation: Xu L, Carpenter-Aeby T, Aeby VG, Lu W, Fisher L, et al. (2016) A Systematic Review of the Literature: Exploring Correlates of Sexual Assault and Homelessness. Trop Med Surg 4: 212. doi:10.4172/2329-9088.1000212

Page 4 of 12

\begin{tabular}{|c|c|c|c|c|c|c|}
\hline $\begin{array}{l}\text { Military Sexual } \\
\text { Trauma (MST) among } \\
\text { homeless veterans. }\end{array}$ & 3 & $\begin{array}{l}\text { Obtained from } \\
\text { Veteran Health } \\
\text { Administrators } \\
\text { database. }\end{array}$ & $\begin{array}{l}\text { National } \\
\text { crosssectiona } \\
\text { I study }\end{array}$ & $\begin{array}{l}\text { VHA Support Service Center } \\
\text { Homeless Registry. }\end{array}$ & $\begin{array}{l}{ }^{*} \mathrm{~N}=126,598 \text {. All analysis } \\
\text { was conducted separately } \\
\text { by gender, comparisons } \\
\text { made by chisquare test. }\end{array}$ & $\begin{array}{l}{ }^{*} \text { Of homeless veterans } 39.7 \% \\
\text { of females and } 3.3 \% \text { of males } \\
\text { have experienced MST. }\end{array}$ \\
\hline $\begin{array}{l}\text { Correlations of adult } \\
\text { assault among } \\
\text { homeless women }\end{array}$ & 4 & $\begin{array}{l}\text { Homeless adults, } \\
\text { who were stratified } \\
\text { by type of site } \\
\text { (homeless shelter, } \\
\text { drug rehab program } \\
\text { or street based) } \\
\text { were informed of the } \\
\text { study by flyers that } \\
\text { were posted in } \\
\text { residential sites or } \\
\text { where participants } \\
\text { received care. } \\
\text { Those interested } \\
\text { called or visited } \\
\text { research nurses in } \\
\text { nearby clinics. }\end{array}$ & Qualitative & 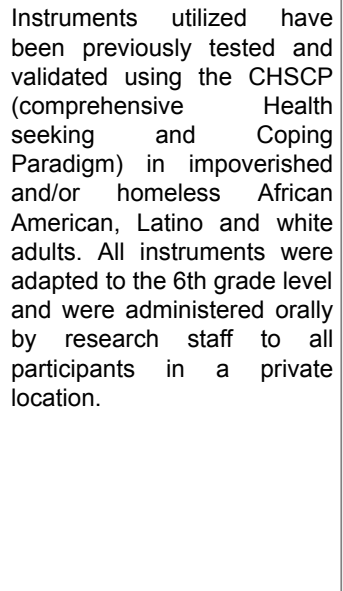 & $\begin{array}{l}{ }^{*} \text { Chi-squared tests and } \\
\text { analysis of variance were } \\
\text { used to assess group } \\
\text { differences in types of } \\
\text { perpetrators abuse. } \\
{ }^{*} \text { Logistic regression } \\
\text { analysis was used to } \\
\text { identify correlates of adult } \\
\text { physical assault, controlling } \\
\text { for important } \\
\text { sociodemographic } \\
\text { characteristics. } \\
{ }^{*} \text { Stepwise multiple logistic } \\
\text { regression modeling was } \\
\text { used to identify correlates } \\
\text { of adult physical and } \\
\text { sexual assault, controlling } \\
\text { for important } \\
\text { sociodemographic } \\
\text { characteristics. }\end{array}$ & $\begin{array}{l}{ }^{*} \text { The sample comprised of } 202 \\
\text { women, the majority were } \\
\text { African American. } \\
{ }^{*} \text { Average age of respondents } \\
\text { was } 42.3(\mathrm{SD}=9.0) \text {. } \\
{ }^{*} \text { Approximately } 33 \% \text { of the } \\
\text { women were raped as adults } \\
\text { and over one-third were } \\
\text { sexually harassed or physically } \\
\text { abused as adults. } \\
{ }^{*} \text { Child sexual abuse was } \\
\text { reported by } 20 \% \text { of women } \\
\text { while almost } 33 \% \text { of the women } \\
\text { had been physically abused as } \\
\text { children; over one-third under } \\
\text { the age of } 18 \text { had been sexually } \\
\text { harassed. } \\
{ }^{*} \text { Ten respondents reported } \\
\text { being raped within the previous } \\
6 \text { months. }\end{array}$ \\
\hline $\begin{array}{l}\text { Homelessness } \\
\text { Related Traumatic } \\
\text { Events and PTSD } \\
\text { among } \\
\text { Experiencing } \\
\text { episodes } \\
\text { homelessness } \\
\text { Three U.S. cities. }\end{array}$ & 5 & $\begin{array}{l}\text { *Systematic random } \\
\text { sample from women } \\
\text { at shelters, meal } \\
\text { locations, and } \\
\text { outdoor locations. } \\
\text { *Interviews and } \\
\text { selfadministered } \\
\text { questionnaires. }\end{array}$ & Qualitative & $\begin{array}{l}\text { The standardized WHOCIDI } \\
\text { algorithm was used to } \\
\text { compute diagnoses based on } \\
\text { criteria outlined in DSM-IV- } \\
\text { TR. }\end{array}$ & $\begin{array}{l}\mathrm{N}=91,62.8 \% \text { raped. } \mathrm{N}=73, \\
50.3 \% \text { sexual assault or } \\
\text { molestation other than } \\
\text { rape. }\end{array}$ & $\begin{array}{l}{ }^{*} 42.6 \% \text { met criteria for lifetime } \\
\text { PTSD and } 29.7 \% \text { met the } \\
\text { criteria for past year PTSD. } \\
{ }^{*} \text { The number of traumatic } \\
\text { events reported ranged from } 0 \\
\text { to } 16 \text { with median of } 6 \text { and } \\
\text { mean of } 6.22\end{array}$ \\
\hline $\begin{array}{lr}\text { The } & \text { high-risk } \\
\text { environment } \quad \text { of } \\
\text { homeless young } \\
\text { adults: Consequences } \\
\text { for physical and } \\
\text { sexual victimization. }\end{array}$ & 6 & 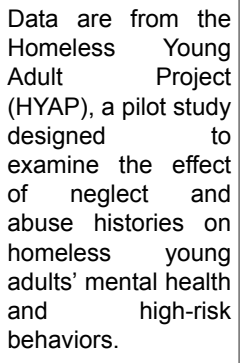 & Qualitative & $\begin{array}{l}\text { Over a period of } \\
\text { approximately } 1 \text { year (from } \\
\text { April of } 2004 \text { through June of } \\
\text { 2005), } 199 \text { young adults were } \\
\text { interviewed in three } \\
\text { Midwestern cities. }\end{array}$ & $\begin{array}{l}{ }^{*} \text { Ages ranged from } 19 \text { to } 26 \\
\text { years with a mean of } 21.5 \\
\text { years. } \\
\text { *The average age at which } \\
\text { youth ran from home was } \\
14.5 \text { years, and most } \\
\text { young people ran } 2 \text { or } 3 \\
\text { times. } \\
\text { *The sample included } 36 \\
\text { females }(28 \%) \text { and } 91 \\
\text { males }(72 \%) \text {. }\end{array}$ & $\begin{array}{l}{ }^{*} \text { The majority of respondents } \\
(94 \%) \text { had experienced some } \\
\text { type of physical victimization } \\
\text { since being on the street, and } \\
32 \% \text { had been sexually } \\
\text { victimized at least once. } \\
{ }^{*} \text { Sixteen percent of youth } \\
\text { reported selling sex, and } 32 \% \\
\text { reported having friends who } \\
\text { have done so. }\end{array}$ \\
\hline 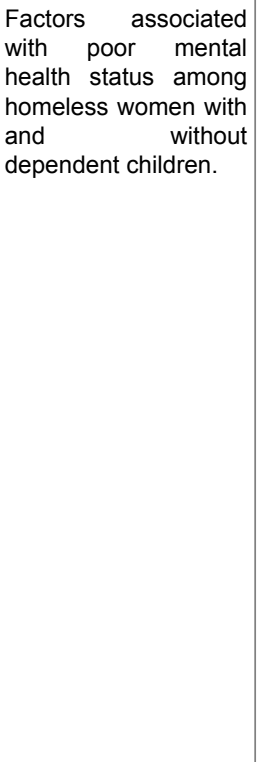 & 7 & 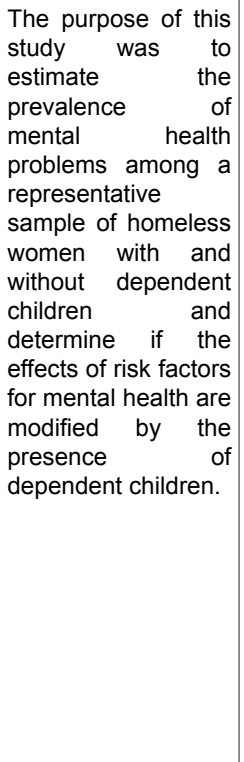 & $\begin{array}{l}\text { Cross } \\
\text { Sectional }\end{array}$ & 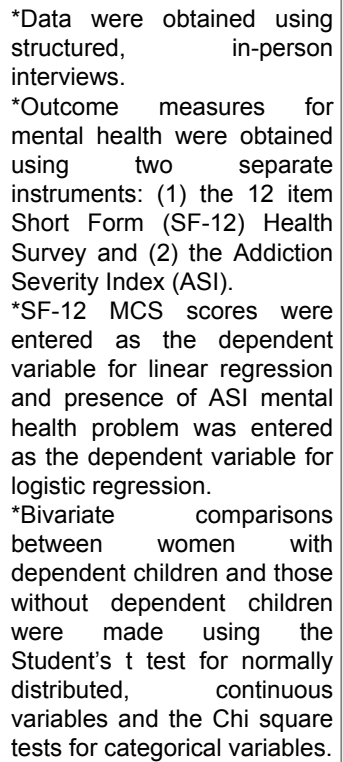 & $\begin{array}{l}\text { *In total, } 522(91.6 \%) \\
\text { women in the study were } \\
\text { included in the analysis, } \\
219(42.0 \%) \text { of whom were } \\
\text { women with dependent } \\
\text { children and } 303(58.0 \%) \\
\text { of whom were women } \\
\text { without dependent children. } \\
{ }^{*} \text { Compared to women } \\
\text { without dependent children, } \\
\text { women with children were } \\
\text { more likely to be } 25-39 \\
\text { years old. }\end{array}$ & $\begin{array}{l}\text { *Mental health problems are } \\
\text { closely associated with the } \\
\text { presence of chronic health } \\
\text { conditions, physical and sexual } \\
\text { assault, drug use, and } \\
\text { perceived access to social } \\
\text { support networks. } \\
\text { *over one-half of our sample } \\
\text { were considered to have either } \\
\text { a mental health or substance } \\
\text { use problem in the past } 12 \\
\text { months, compared to } \\
\text { approximately } 11 \% \text { of Canadian } \\
\text { women who experience } \\
\text { symptoms of depression, mood } \\
\text { disorders, } \\
\text { anxiety disorders, or substance } \\
\text { dependence. }\end{array}$ \\
\hline
\end{tabular}


Citation: Xu L, Carpenter-Aeby T, Aeby VG, Lu W, Fisher L, et al. (2016) A Systematic Review of the Literature: Exploring Correlates of Sexual Assault and Homelessness. Trop Med Surg 4: 212. doi:10.4172/2329-9088.1000212

Page 5 of 12

\begin{tabular}{|c|c|c|c|c|c|c|}
\hline $\begin{array}{l}\text { Discrepancies in } \\
\text { reporting of physical } \\
\text { and sexual abuse } \\
\text { among homeless } \\
\text { young adults. }\end{array}$ & 8 & $\begin{array}{lr}\text { This } & \text { study } \\
\text { investigated } & \text { risk } \\
\text { factors } & \text { for } \\
\text { discrepant } & \text { reporting } \\
\text { of physical } & \text { and } \\
\text { sexual } & \text { abuse } \\
\text { among } & 172 \\
\text { homeless } & \text { young } \\
\text { adults. } & \end{array}$ & $\begin{array}{l}\text { Cross } \\
\text { Sectional }\end{array}$ & $\begin{array}{l}\text { *Demographic } \\
\text { Characteristics: age, gender, } \\
\text { race, sexual orientation and } \\
\text { education. } \\
\text { *Family Background } \\
\text { Characteristics: Foster care, } \\
\text { warmth, neglect, physical } \\
\text { abuse, sexual abuse. } \\
\text { *Discrepant Reporting: } \\
\text { Discrepant reporting of } \\
\text { physical and sexual abuse. }\end{array}$ & $\begin{array}{l}\text { *The sample included } 69 \\
\text { females }(40.1 \%) \text { and } 103 \\
\text { males }(59.9 \%) \text {. Of these, } \\
31 \text { respondents (18.5\%) } \\
\text { selfidentified as gay, } \\
\text { lesbian, or bisexual (GLB). } \\
\text { *The sample included } 69 \\
\text { females }(40.1 \%) \text { and } 103 \\
\text { males }(59.9 \%) \text {. } \\
{ }^{*} \text { The actual age of the } \\
\text { sample ranged from } 19 \text { to } \\
26 \text { years with a mean of } \\
21.45 \text { years. } \\
{ }^{*} \text { The majority of the sample } \\
\text { was White (80\%) but } 9 \% \\
\text { were Black or African } \\
\text { American, } 4 \% \text { Hispanic or } \\
\text { Latino, } 2 \% \text { American Indian } \\
\text { or Alaskan Native, } 1 \% \\
\text { Asian, and } 5 \% \text { biracial or } \\
\text { multiracial. }\end{array}$ & $\begin{array}{l}\text { * } 31 \% \text { of the respondents were } \\
\text { discrepant reporters on this } \\
\text { minor abuse item. } \\
\text { *In terms of severe physical } \\
\text { abuse, } 14 \text { denied ever } \\
\text { experiencing Physical abuse, } \\
\text { resulting in a } 31 \% \text { discrepant } \\
\text { reporting on this item. } \\
\text { *In terms of very severe } \\
\text { physical abuse, when asked } \\
\text { about being grabbed around the } \\
\text { neck and choked by a } \\
\text { caretaker, six respondents } \\
\text { confirmed that they had been } \\
\text { very severely abused in this } \\
\text { manner although they denied } \\
\text { experiencing physical abuse in } \\
\text { general. This resulted in } 25 \% \text { of } \\
\text { respondents being discrepant } \\
\text { reporters on this item. }\end{array}$ \\
\hline $\begin{array}{l}\text { Military sexual assault } \\
\text { and homeless women } \\
\text { veterans. }\end{array}$ & 9 & $\begin{array}{l}\text { This observational } \\
\text { study compared } \\
\text { clinical symptoms, } \\
\text { pre-military } \\
\text { experiences, and } \\
\text { treatment } \\
\text { preferences among } \\
509 \text { female veterans } \\
\text { with and without } \\
\text { MSA who enrolled in } \\
11 \text { VA Homeless } \\
\text { Women Veterans } \\
\text { Programs. }\end{array}$ & $\begin{array}{l}\text { Observationa } \\
\text { I study }\end{array}$ & $\begin{array}{l}\text { Demographic information was } \\
\text { collected, including } \\
\text { information on race and } \\
\text { ethnicity, marital status, } \\
\text { branch of military service, use } \\
\text { of any federal or state aid } \\
\text { program in the last } 2 \text { years, } \\
\text { and duration of } \\
\text { homelessness. }\end{array}$ & $\begin{array}{l}\text { *First, the proportion of } \\
\text { homeless female veterans } \\
\text { reporting MSA is } \\
\text { presented. } \\
\text { *Next descriptive statistics, } \\
\text { odds ratios, and t-tests } \\
\text { were conducted to } \\
\text { compare homeless female } \\
\text { veterans who did and did } \\
\text { not report MSA on } \\
\text { demographic and clinical } \\
\text { variables, recent } \\
\text { victimization, } \\
\text { experienced before entry } \\
\text { into the military, and } \\
\text { interest in treatment. }\end{array}$ & $\begin{array}{l}\text { *Over one third of participants } \\
(41.1 \%) \text { reported MSA. } \\
\text { *In multivariate analyses, } \\
\text { homeless female veterans who } \\
\text { reported MSA endorsed greater } \\
\text { severity of PTSD and other } \\
\text { psychiatric symptoms. } \\
\text { * Of the } 509 \text { homeless women } \\
\text { veterans in the study, } 209 \\
(41.1 \%) \text { reported experiencing } \\
\text { MSA. In bivariate analyses, } \\
\text { participants who reported MSA } \\
\text { were more likely to be currently } \\
\text { married and to endorse greater } \\
\text { severity of PTSD and } \\
\text { psychiatric symptoms. }\end{array}$ \\
\hline $\begin{array}{llr}\text { Physical and sexual } \\
\text { abuse history in } \\
\text { women } & \text { seeking } \\
\text { treatment } & \text { at } & \text { a } \\
\text { psychiatric } & \text { clinic } & \text { for } \\
\text { the homeless. } & \end{array}$ & 10 & $\begin{array}{l}\text { Records of initial } \\
\text { psychiatric } \\
\text { evaluations obtained } \\
\text { from all female } \\
\text { patients receiving } \\
\text { services at the I.M. } \\
\text { Sulzbacher } \\
\text { Homeless Shelter } \\
\text { mental health clinic } \\
\text { in Jacksonville, } \\
\text { Florida during a 16- } \\
\text { month period (from } \\
\text { July 2000 through } \\
\text { November 2001) } \\
\text { were reviewed to } \\
\text { determine } \\
\text { demographic } \\
\text { characteristics, } \\
\text { abuse history, and } \\
\text { psychiatric } \\
\text { diagnoses. } \\
\text { *Of the } 138 \text { records } \\
\text { reviewed, only the } \\
99 \text { that contained } \\
\text { documentation of } \\
\text { positive or negative } \\
\text { abuse history were } \\
\text { analyzed. }\end{array}$ & $\begin{array}{l}\text { Multivariable } \\
\text { logistic } \\
\text { regression }\end{array}$ & $\begin{array}{l}\text { *Assessed the association } \\
\text { between age and the } \\
\text { presence or absence of } \\
\text { abuse using the Student's } t \\
\text { test. } \\
{ }^{*} \text { Assessed association } \\
\text { between each dichotomous } \\
\text { predictor and abuse using } \\
\text { chi-square tests. } \\
{ }^{*} \text { Descriptive statistics, } \\
\text { univariate analyses, and } \\
\text { multivariable logistic } \\
\text { regression were performed } \\
\text { using SAS } 9.1 .3 \text { software. } \\
{ }^{*} \text { For the analysis, race was } \\
\text { dichotomized while age was } \\
\text { analyzed continuously. }\end{array}$ & $\begin{array}{l}\text { The study population as a } \\
\text { whole was } 64 \% \text { white, } 33 \% \\
\text { African-American, and } 2 \% \\
\text { Hispanic, with a mean age } \\
\text { of } 36.8( \pm 9.6) \text { years. }\end{array}$ & $\begin{array}{l}{ }^{*} \text { Rates of substance abuse and } \\
\text { mood disorders diagnoses did } \\
\text { not differ significantly between } \\
\text { abused and non-abused } \\
\text { subjects. } \\
{ }^{*} \text { Rates of anxiety disorders } \\
\text { between abused }(54.8 \%) \text { and } \\
\text { non-abused }(15.4 \%) \text { subjects } \\
\text { did differ significantly. }\end{array}$ \\
\hline $\begin{array}{l}\text { Gender differences in } \\
\text { victimized homeless } \\
\text { adolescents. }\end{array}$ & 11 & $\begin{array}{l}\text { *Homeless } \\
\text { adolescents who } \\
\text { received health and } \\
\text { social services from } \\
\text { a street outreach } \\
\text { program were }\end{array}$ & $\begin{array}{l}\text { A secondary } \\
\text { analysis of } \\
\text { data } \\
\text { collected for } \\
\text { a previous } \\
\text { crosssectiona }\end{array}$ & $\begin{array}{l}\text { *Multivariate analysis of } \\
\text { variance (MANOVA), which } \\
\text { takes into consideration } \\
\text { intercorrelations among the } \\
\text { measures and controls the } \\
\text { overall level of significance, }\end{array}$ & $\begin{array}{l}\text { *Participants consisted of } \\
414 \text { youths }(104 \text { males who } \\
\text { reported sexual abuse and } \\
124 \text { who did not; and } 95 \\
\text { females who reported } \\
\text { sexual abuse and } 75 \text { who }\end{array}$ & $\begin{array}{l}{ }^{*} \text { The median age at first } \\
\text { intercourse was } 14 \text { years. } \\
{ }^{*} \text { Age at first voluntary } \\
\text { intercourse ranged from } 14.17 \\
\text { for the Non-abused males to } \\
14.70 \text { for those abused. }\end{array}$ \\
\hline
\end{tabular}


Citation: Xu L, Carpenter-Aeby T, Aeby VG, Lu W, Fisher L, et al. (2016) A Systematic Review of the Literature: Exploring Correlates of Sexual Assault and Homelessness. Trop Med Surg 4: 212. doi:10.4172/2329-9088.1000212

Page 6 of 12

\begin{tabular}{|c|c|c|c|c|c|c|}
\hline & & $\begin{array}{l}\text { invited by social } \\
\text { services personnel } \\
\text { to participate in the } \\
\text { study. } \\
\text { *Those re who } \\
\text { indicated r a } \\
\text { willingness } r \text { to } \\
\text { participate, gave } \\
\text { written informed } \\
\text { consent, completed } \\
\text { a written survey, and } \\
\text { received a snack } \\
\text { and } \$ 10 .\end{array}$ & $\begin{array}{l}\text { I study of the } \\
\text { sexual health } \\
\text { practices of } \\
\text { homeless } \\
\text { adolescents. }\end{array}$ & $\begin{array}{l}\text { was used to examine group } \\
\text { differences on the basis of } \\
\text { their centroids. } \\
\text { *For each measure, intra- } \\
\text { class reliability coefficient } \\
\text { was estimated, using } \\
\text { Cronbach's Coefficient Alpha. } \\
\text { *The Statistical Package for } \\
\text { Social Sciences (SPSS) was } \\
\text { employed for the purpose of } \\
\text { data entry, manipulation, and } \\
\text { analysis. }\end{array}$ & $\begin{array}{l}\text { did not; } 16 \text { with missing } \\
\text { data). } \\
\text { *The participants were } \\
\text { primarily Anglo American } \\
(76.1 \%) \text {, heterosexual } \\
(63.3 \%) \text { with a mean age of } \\
18.46 \text { years }(\mathrm{SD}=1.29) \text {. }\end{array}$ & $\begin{array}{l}\text { *There is evidence from this } \\
\text { study that although males and } \\
\text { females are similar in many } \\
\text { respects, abuse victims differ in } \\
\text { terms of their cognitive and } \\
\text { behavioral factors and } \\
\text { associated sexual health } \\
\text { practices. }\end{array}$ \\
\hline $\begin{array}{lr}\text { Prevalence } & \text { of } \\
\text { childhood } & \text { abuse } \\
\text { among people who } \\
\text { are homeless in } \\
\text { Western countries. }\end{array}$ & 12 & $\begin{array}{l}\text { Twenty-four reports } \\
\text { published between } \\
\text { January } 1990 \text { and } \\
\text { August } 2013 \text { in } \\
\text { three } \quad \text { countries } \\
\text { provided estimates } \\
\text { obtained from up to } \\
9,730 \quad \text { adult } \\
\text { individuals r who } \\
\text { were homeless. }\end{array}$ & $\begin{array}{l}\text { Systematic } \\
\text { review }\end{array}$ & $\begin{array}{l}\text { *Substantial heterogeneity } \\
\text { was observed among the } \\
\text { studies (I2 C } 98 \%) \text {. Most } \\
\text { involved a single nterview or } \\
\text { questionnaire item, however, } \\
\text { five studies use psychometric } \\
\text { instruments. } \\
\text { *For studies where both CPA } \\
\text { and CSA data are reported, N } \\
\text { is usually identical for each } \\
\text { measure, but in a few } \\
\text { instances sample sizes differ } \\
\text { for CPA and CSA. } \\
{ }^{*} \text { This included four using the } \\
\text { Childhood Trauma } \\
\text { Questionnaire (CTQ) }\end{array}$ & $\begin{array}{l}\text { Sources of heterogeneity in } \\
\text { the prevalence rates were } \\
\text { explored by meta- } \\
\text { regression analysis. }\end{array}$ & $\begin{array}{l}{ }^{*} \text { Prevalence of } \begin{array}{c}\text { reported } \\
\text { childhood physical abuse }\end{array} \\
\text { ranged from } 6 \text { to } 94 \% \text { with } \\
\text { average prevalence of } 37 \%, 95 \\
\% \mathrm{Cl} \text {. } \\
{ }^{*} \text { Reported sexual abuse ranged } \\
\text { from } 4 \text { to } 62 \% \text {, with average } \\
\text { prevalence estimated as } 32 \% \text {, } \\
95 \% \mathrm{Cl} \text { for female and } 10 \% \text { for } \\
\text { male, } 95 \% \mathrm{Cl} \text {. }\end{array}$ \\
\hline $\begin{array}{lr}\text { Exploring } & \text { the } \\
\text { psychosocial } & \text { and } \\
\text { behavioral adjustment } \\
\text { outcomes of } \\
\text { type abuse } & \text { among } \\
\text { homeless } & \text { young } \\
\text { adults. } & \end{array}$ & 13 & $\begin{array}{lr}\text { In this cross- } \\
\text { sectional } & \text { study, } \\
\text { convenience } & \\
\text { sampling was } & \text { used } \\
\text { to select } & 28 \\
\text { homeless young } \\
\text { adults (ages } & 18 \text { to } \\
\text { 24) from a homeless } \\
\text { youth drop-in center. }\end{array}$ & $\begin{array}{l}\text { Cross } \\
\text { Sectional } \\
\text { Study }\end{array}$ & $\begin{array}{l}\text { *Mental health status } \\
\text { comprised three variables: } \\
\text { depressive symptoms, } \\
\text { internalizing behaviors, and } \\
\text { externalizing behaviors. } \\
\text { *Internalizing and } \\
\text { externalizing behaviors were } \\
\text { assessed using the Adult } \\
\text { Self-Report (ASR). } \\
{ }^{*} \text { Chi-square and Fishers } \\
\text { exact tests were used to } \\
\text { assess group differences in } \\
\text { categorical psychosocial and } \\
\text { behavioral variables and the } \\
\text { abuse variable. }\end{array}$ & $\begin{array}{l}{ }^{*} \text { Of the six types, } \\
\text { participants experienced an } \\
\text { average of } 2.96 \text { types of } \\
\text { abuse }(\mathrm{SD}=1.88, \\
\text { Mdn=3.00). } \\
{ }^{*} \text { Seventy-one percent } \\
(\mathrm{H}=20) \text { reported histories of } \\
\text { three or more types, with } \\
18 \% \quad(n=5) \text { experiencing } \\
\text { five or six types. }\end{array}$ & $\begin{array}{l}{ }^{*} \text { Among the } 23 \text { of the } 28 \\
\text { subjects with at least one abuse } \\
\text { type, } 65 \% \text { were previously in } \\
\text { foster care (compared with } 57 \% \\
\text { of the sample of abused and } \\
\text { nonabused subjects). } \\
{ }^{*} \text { The mean age at which these } \\
\text { youths entered foster care was } \\
8.3 .^{\wedge} \text { years (SD = } 4.69 \text { ) } \\
\text { (compared with } 9.00 \text { years in } \\
\text { the full sample), and the } \\
\text { average number of placements } \\
\text { was } 3.27(S D=2.52 \text { ). }\end{array}$ \\
\hline $\begin{array}{l}\text { Community } \\
\text { characteristics and } \\
\text { violence against } \\
\text { homeless women in } \\
\text { Los Angeles County. }\end{array}$ & 14 & $\begin{array}{l}\text { Participants were } \\
\text { interviewed at } 66 \\
\text { assistance } \\
\text { programs in Los } \\
\begin{array}{l}\text { Angeles County, } \\
\text { California. }\end{array}\end{array}$ & $\begin{array}{l}\text { Probability- } \\
\text { based } \\
\text { sampling } \\
\text { design }\end{array}$ & $\begin{array}{l}\text { Sampling proceeded in two } \\
\text { stages: (1) selection of } 78 \\
\text { sites stratified by } 8 \text { regions of } \\
\text { LA County (e.g., Downtown, } \\
\text { Westside, Hollywood) and by } \\
\text { type of site (shelter versus } \\
\text { meal program); and (2) } \\
\text { selection of visits by } \\
\text { homeless women at the sites. }\end{array}$ & $\begin{array}{l}\text { Intra-class correlation (ICC) } \\
\text { estimates showed that the } \\
\text { proportion of between-ZIP } \\
\text { code variance was } 7.4 \% \\
\text { for sexual assault (chi- } \\
\text { squared }=7.60 ; p=.003 \text { ) and } \\
3.7 \% \text { for physical assault } \\
\text { (chi-squared=3.51; } p=.03 \text { ). }\end{array}$ & $\begin{array}{l}\text { *Approximately } 33 \% \text { of } \\
\text { respondents had been } \\
\text { physically assaulted, and } 14 \% \\
\text { had been sexually assaulted, at } \\
\text { least once in the previous } 12 \\
\text { months. } \\
{ }^{*} \text { Approximately } 85 \% \text { of the } \\
\text { women belonged to racial/ } \\
\text { ethnic minority groups, and the } \\
\text { average age was } 33 \text { years old. }\end{array}$ \\
\hline $\begin{array}{lr}\text { Victimization } & \text { and } \\
\text { posttraumatic } & \text { stress } \\
\text { disorder } & \text { among } \\
\text { runaway } & \text { and } \\
\text { homeless } & \\
\text { adolescents. } & \end{array}$ & 15 & $\begin{array}{l}\text { The data was } \\
\text { collected by full-time } \\
\text { street interviewers } \\
\text { on the streets and in } \\
\text { shelters in eight } \\
\text { Midwestern cities of } \\
\text { various populations. }\end{array}$ & $\begin{array}{l}\text { Longitudinal } \\
\text { diagnostic } \\
\text { study }\end{array}$ & $\begin{array}{l}\text { *The UM-CIDI was used to } \\
\text { assess major depressive } \\
\text { episode, PTSD, alcohol } \\
\text { abuse, and drug abuse. } \\
{ }^{*} \text { To assess behavioral } \\
\text { problems, the conduct } \\
\text { disorder module was used } \\
\text { from the DISC-R. }\end{array}$ & $\begin{array}{l}{ }^{*} \text { Rates of lifetime PTSD } \\
\text { have been estimated to be } \\
\text { in the range of } 10 \%-12 \% \\
\text { for women, and } 5 \%-6 \% \text { for } \\
\text { men. } \\
{ }^{*} \text { PTSD rates for young } \\
\text { persons aged } 15 \text { to } 24 \\
\text { years from the National } \\
\text { Comorbidity Survey were } \\
10.3 \% \text { for women and } \\
2.8 \% \text { for men. } \\
\text { *Using data from a national } \\
\text { probability sample, } \\
\text { Kilpatrick et al. }(2003) \\
\text { reported rates of } 3.7 \% \text { for }\end{array}$ & $\begin{array}{l}{ }^{*} \text { About one-third }(35.5 \%) \text { of the } \\
\text { runaways met lifetime criteria } \\
\text { for PTSD and } 16.1 \% \text { met } 12- \\
\text { month criteria for the disorder. } \\
{ }^{*} \text { More than } 90 \% \text { of the } \\
\text { adolescents who met criteria for } \\
\text { PTSD met criteria for at least } \\
\text { one of the other four diagnoses. } \\
{ }^{*} \text { Almost one-half } \\
\text { of the runaways }{ }^{*} \text { About one- } \\
\text { third ( } 35.5 \% \text { of the runaways } \\
\text { met lifetime criteria for PTSD } \\
\text { and } 16.1 \% \text { met } 12-\text {-month } \\
\text { criteria for the disorder. } \\
{ }^{*} \text { More than } 90 \% \text { of the } \\
\text { adolescents who met criteria for }\end{array}$ \\
\hline
\end{tabular}


Citation: $\quad$ Xu L, Carpenter-Aeby T, Aeby VG, Lu W, Fisher L, et al. (2016) A Systematic Review of the Literature: Exploring Correlates of Sexual Assault and Homelessness. Trop Med Surg 4: 212. doi:10.4172/2329-9088.1000212

\begin{tabular}{|c|c|c|c|c|c|c|}
\hline & & & & & $\begin{array}{l}\text { boys and } 6.3 \% \text { for girls } \\
\text { aged } 12-17 .\end{array}$ & $\begin{array}{l}\text { PTSD met criteria for at least } \\
\text { one of the other four diagnoses. } \\
\text { *Almost one-half } \\
\text { of the runaways *About one- } \\
\text { third ( } 35.5 \% \text { ) of the runaways } \\
\text { met lifetime criteria for PTSD } \\
\text { and } 16.1 \% \text { met } 12-\text {-month } \\
\text { criteria for the disorder. } \\
\text { *More than } 90 \% \text { of the } \\
\text { adolescents who met criteria for } \\
\text { PTSD met criteria for at least } \\
\text { one of the other four diagnoses. } \\
{ }^{*} \text { Almost one-half } \\
\text { of the runaways }{ }^{*} \text { About one- } \\
\text { third ( } 35.5 \%) \text { of the runaways } \\
\text { met lifetime criteria for PTSD } \\
\text { and } 16.1 \% \text { met } 12-\text { month } \\
\text { criteria for the disorder. } \\
\text { *More than } 90 \% \text { of the } \\
\text { adolescents who met criteria for } \\
\text { PTSD met criteria for at least } \\
\text { one of the other four diagnoses. } \\
\text { *Almost one-half of the } \\
\text { runaways } \\
\text { *About one-third (35.5\%) of the } \\
\text { runaways met lifetime criteria } \\
\text { for PTSD and } 16.1 \% \text { met } 12- \\
\text { month criteria for the disorder. } \\
\text { *More than } 90 \% \text { of the } \\
\text { adolescents who met criteria for } \\
\text { PTSD met criteria for at least } \\
\text { one of the other four diagnoses. } \\
{ }^{*} \text { Almost one-half of the } \\
\text { runaways ( } 48 \% \text { who met } \\
\text { criteria for PTSD also met } \\
\text { criteria for major depressive } \\
\text { disorder. }\end{array}$ \\
\hline $\begin{array}{l}\text { Neurobehavioral and } \\
\text { cognitive function is } \\
\text { linked to childhood } \\
\text { trauma in homeless } \\
\text { adults. }\end{array}$ & 16 & $\begin{array}{l}\text { A sample of } 55 \\
\text { homeless adults } \\
\text { was recruited from } \\
\text { homeless services } \\
\text { in the city of } \\
\text { Sheffield, UK. All } \\
\text { were interviewed to } \\
\text { acquire substance } \\
\text { misuse information, } \\
\text { record experiences } \\
\text { of childhood trauma, } \\
\text { and assess } \\
\text { cognitive and } \\
\text { neurobehavioral } \\
\text { traits. }\end{array}$ & Qualitative & $\begin{array}{l}\text { *Childhood Trauma } \\
\text { Questionnaire. } \\
{ }^{*} \text { Participants also completed } \\
\text { the Wechsler Abbreviated } \\
\text { Scale of Intelligence and the } \\
\text { FrSBe, which was completed } \\
\text { with respect to current } \\
\text { behavior and conduct prior to } \\
\text { homelessness. } \\
\text { *Comparisons between } \\
\text { FrSBe scores } \\
\text { performed with t tests, } \\
\text { including one-sample, paired- } \\
\text { sample, and Independent- } \\
\text { sample tests as appropriate. } \\
\text { *All analyses were performed } \\
\text { with SPSS 14. }\end{array}$ & $\begin{array}{l}{ }^{*} \text { Around three-quarters of } \\
\text { the sample scored in the } \\
\text { clinically significant range } \\
\text { for current neurobehavioral } \\
\text { impairment. } \\
{ }^{*} \text { The mean group IQ was } \\
\text { below average at } 88 \text {. }\end{array}$ & $\begin{array}{l}{ }^{*} \text { Abuse or neglect during their } \\
\text { upbringing was reported by } \\
89 \% \text { of the sample. } \\
{ }^{*} \text { Evidence suggests that these } \\
\text { neuropsychological factors may, } \\
\text { in part, constitute a long-term } \\
\text { consequence of childhood } \\
\text { trauma. }\end{array}$ \\
\hline $\begin{array}{ll}\text { Prevalence } & \text { of } \\
\text { histories of abuse in } \\
\text { homeless youth. }\end{array}$ & 17 & $\begin{array}{l}\text { Homeless and street } \\
\text { involved persons } \\
\text { aged } 18-23 \text { filled out } \\
\text { a questionnaire and } \\
\text { participated in } \\
\text { structured } \\
\text { assessments of } \\
\text { abuse, substance } \\
\text { abuse and tobacco. }\end{array}$ & $\begin{array}{l}\text { Empirical } \\
\text { study, } \\
\text { interview, } \\
\text { quantitative } \\
\text { study }\end{array}$ & $\begin{array}{l}2 \text { part assessment- starting } \\
\text { with a } 70 \text { item questionnaire } \\
\text { about childhood experiences } \\
\text { and current behavior. Next } \\
\text { participants completed a } \\
\text { structured interview to assess } \\
\text { perceived effects and } \\
\text { motivation to engage in } \\
\text { treatment. Two-sided Fisher's } \\
\text { exact tests were calculated to } \\
\text { compare study subjects. }\end{array}$ & $\begin{array}{l}\text { Adverse childhood } \\
\text { experiences questionnaire. }\end{array}$ & $\begin{array}{l}\text { Abuse victims who were } \\
\text { interested in treatment were } \\
\text { more likely to not have } \\
\text { graduated high school. The } \\
\text { higher the education, the higher } \\
\text { the resistance to treatment. } \\
80 \% \text { of participants reported } \\
\text { some history of childhood } \\
\text { abuse. }\end{array}$ \\
\hline $\begin{array}{l}\text { Risk factors for sexual } \\
\text { victimization among } \\
\text { gay, lesbian, bisexual } \\
\text { and heterosexual } \\
\text { homeless young } \\
\text { adults. }\end{array}$ & 18 & 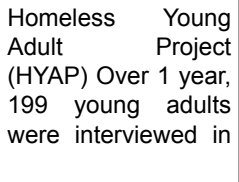 & $\begin{array}{l}\text { Empirical } \\
\text { study, } \\
\text { quantitative } \\
\text { study, } \\
\text { Systematic }\end{array}$ & $\begin{array}{lrr}\text { Parent-child conflict } & \text { tactics } \\
\text { scale. Center } & \text { for } \\
\text { epidemiologic } & \text { studies } \\
\text { depression scale. } & \end{array}$ & $\begin{array}{l}69 \text { females, } 103 \text { males. Of } \\
\text { these } 31 \text { self-identified as } \\
\text { gay, lesbian or bisexual. } \\
\text { Age sampled ranged from } \\
19-26 \text { years old. }\end{array}$ & $\begin{array}{l}\text { Sexual victimization was } \\
\text { positively associated with being } \\
\text { sexually abused, higher levels } \\
\text { of neglect, being depressed, } \\
\text { having traded sex, having }\end{array}$ \\
\hline
\end{tabular}


Citation: Xu L, Carpenter-Aeby T, Aeby VG, Lu W, Fisher L, et al. (2016) A Systematic Review of the Literature: Exploring Correlates of Sexual Assault and Homelessness. Trop Med Surg 4: 212. doi:10.4172/2329-9088.1000212

Page 8 of 12

\begin{tabular}{|c|c|c|c|c|c|c|}
\hline & & $\begin{array}{l}\text { three Midwestern } \\
\text { cities. }\end{array}$ & $\begin{array}{l}\text { Sampling } \\
\text { Strategy }\end{array}$ & & & $\begin{array}{l}\text { prostituted and having friends } \\
\text { who have traded for sex. }\end{array}$ \\
\hline $\begin{array}{l}\text { Relationship of sexual } \\
\text { abuse and perceived } \\
\text { well-being among } \\
\text { homeless youth. }\end{array}$ & 19 & $\begin{array}{lr}\begin{array}{l}\text { Surveys, } \\
\text { group }\end{array} & \text { focus } \\
\text { and } & \text { individual } \\
\text { interviews. }\end{array}$ & $\begin{array}{l}\text { Empirical } \\
\text { study. } \\
\text { Triangulate } \\
\text { design was } \\
\text { used to } \\
\text { analyze } \\
\text { quantitative } \\
\text { data provided } \\
\text { by } \\
\text { participants. }\end{array}$ & $\begin{array}{l}\text { Items for quantitative survey } \\
\text { were taken from Adolescent } \\
\text { Health Survey (AHS), UCLA- } \\
\text { R Loneliness scale and the } \\
\text { General Health Rating Index } \\
\text { (GHRI). }\end{array}$ & $\begin{array}{l}\text { Quantitative data were } \\
\text { analyzed by computing } \\
\text { Pearson product-moment } \\
\text { and point bi-serial } \\
\text { correlations. Nearly } 2 \text { out of } \\
3 \text { participants reported a } \\
\text { history of sexual abuse. }\end{array}$ & $\begin{array}{l}\text { Significant relationships among } \\
\text { sexual abuse, connectedness, } \\
\text { loneliness and perceived well- } \\
\text { being. Sexual abuse was } \\
\text { significantly related to } \\
\text { loneliness. }\end{array}$ \\
\hline $\begin{array}{l}\text { Coping mediates the } \\
\text { relationship between } \\
\text { PTSD symptoms and } \\
\text { alcohol use in } \\
\text { homeless, ethnically } \\
\text { diverse women. }\end{array}$ & 20 & $\begin{array}{l}23 \text { women were } \\
\text { recruited from local } \\
\text { homeless shelters } \\
\text { who reported } \\
\text { alcohol use in the } \\
\text { last } 30 \text { days and } \\
\text { prior to trauma. }\end{array}$ & $\begin{array}{l}\text { Empirical } \\
\text { study; } \\
\text { quantitative } \\
\text { study }\end{array}$ & $\begin{array}{lr}\text { Timeline follow } & \text { back (TLFB), } \\
\text { Drinking } & \text { Motives } \\
\text { Questionnaire } & (D M Q) \text { and } \\
\text { Posttraumatic } & \text { Diagnostic } \\
\text { Scale (PDS). } & \end{array}$ & $\begin{array}{l}\text { Participants drank on } \\
\text { approximately } 1 / 3 \text { of the } \\
\text { last } 30 \text { days. Women } \\
\text { reported drinking heavily } \\
\text { on days they consumed } \\
\text { alcohol. }\end{array}$ & $\begin{array}{l}\text { Results suggest that homeless } \\
\text { may be "self-medicating" to } \\
\text { ameliorate their trauma } \\
\text { symptoms. }\end{array}$ \\
\hline 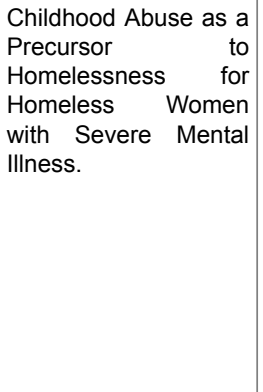 & 21 & $\begin{array}{l}\text { Large experiment } \\
\text { looking at delivery of } \\
\text { independent } \\
\text { housing } \\
\begin{array}{l}\text { supportive with } \\
\text { management }\end{array} \text { case } \\
\text { homeless } \\
\text { individuals } \\
\text { severe with } \\
\begin{array}{l}\text { illness in San Diego } \\
\text { County. }\end{array}\end{array}$ & Qualitative & $\begin{array}{l}\text { The measure concentrated } \\
\text { on three areas of the } \\
\text { women's experiences: } \\
\text { a)abuse during childhood, } \\
\text { both physical and sexual, b) } \\
\text { age of onset of } \\
\text { homelessness, and c)several } \\
\text { different aspects of mental } \\
\text { health hypothesized to relate } \\
\text { to childhood abuse, including } \\
\text { depression, suicidality, and } \\
\text { the presence of PTSD. }\end{array}$ & $\begin{array}{l}\mathrm{N}=28 \quad 23.3 \% \text { no abuse. } \\
\mathrm{N}=71 \quad 59.2 \% \text { physically } \\
\text { abused. } \\
\mathrm{N}=6755.8 \% \text { Sexual abuse } \\
\text { (total). } \\
\mathrm{N}=31 \quad 25.8 \% \quad \text { sexually } \\
\text { abused by an adult } \\
\text { member of the household. } \\
\mathrm{N}=53 \quad 44.2 \% \text { sexually } \\
\text { abused by an adult outside } \\
\text { of the household. } \\
\mathrm{N}=46 \quad 38.3 \% \text { both physical } \\
\text { and sexual abuse. }\end{array}$ & $\begin{array}{l}\text { The results of the investigation } \\
\text { confirm that physical and sexual } \\
\text { abuse are highly prevalent in } \\
\text { the backgrounds of many } \\
\text { homeless women with mental } \\
\text { illness. }\end{array}$ \\
\hline $\begin{array}{lr}\text { Maltreatment } & \text { Among } \\
\text { Runaway } & \text { and } \\
\text { Homeless Youth. }\end{array}$ & 22 & $\begin{array}{l}\text { Data was received } \\
\text { from the STAR } \\
\text { project, a federal } \\
\text { research and } \\
\text { demonstration } \\
\text { project designed to } \\
\text { strengthen services } \\
\text { to runaway and } \\
\text { homeless youth and } \\
\text { their families. The } \\
\text { sample included } 223 \\
\text { youth who sought } \\
\text { services from } 9 \\
\text { runaway and } \\
\text { homeless youth } \\
\text { programs in N.Y. } \\
\text { State. }\end{array}$ & Qualitative & $\begin{array}{l}\text { Two instruments were used } \\
\text { to collect data. First, a semi } \\
\text { structured questionnaire, the } \\
\text { STAR Maltreatment } \\
\text { Questionnaire. The second } \\
\text { was the Youth Information } \\
\text { Form (YIF), is routinely used } \\
\text { by the federal government to } \\
\text { gather information and } \\
\text { monitor the R\&HY programs } \\
\text { which it funds. }\end{array}$ & $\begin{array}{l}\text { Majority of female sought } \\
\text { services between the ages } \\
\text { of } 15-17 \text { and males sought } \\
\text { services between the ages } \\
\text { of } 16-17 \text {. Across all data } \\
\text { sets, girls were more likely } \\
\text { to be identified as } \\
\text { runaways while boys were } \\
\text { more likely to be identified } \\
\text { as homeless. }\end{array}$ & $\begin{array}{l}\text { Female adolescents were more } \\
\text { likely to be identified as having } \\
\text { been maltreated. Girls are } \\
\text { perceived to be in greater } \\
\text { danger and need of protection; } \\
\text { staff may therefore be more } \\
\text { likely to suspect abuse and } \\
\text { neglect among females. Young } \\
\text { people who seek services from } \\
\text { R\&HY programs manifest a } \\
\text { variety of problems: depression, } \\
\text { poor self-image, alcohol and } \\
\text { drug dependence, academic } \\
\text { dysfunction, and suicidal } \\
\text { behavior. }\end{array}$ \\
\hline $\begin{array}{l}\text { On the Outside: The } \\
\text { Needs of } \\
\text { Unsupported, } \\
\text { Homeless Youth. }\end{array}$ & 23 & $\begin{array}{l}\text { Analyzed rase } \\
\text { studies of the } \\
\text { applicants and both } \\
\text { Frank Mass and } \\
\text { Robyn Hartley } \\
\text { contributed to } \\
\text { writing the report. }\end{array}$ & $\begin{array}{l}\text { Policy } \\
\text { background } \\
\text { paper }\end{array}$ & $\begin{array}{l}\text { The Institute report which } \\
\text { resulted from the } \\
\text { Commonwealth request, } \\
\text { entitled 'On the outside: } \\
\text { assessment of the needs of } \\
\text { unsupported students' (Maas, } \\
\text { 1986), reviewed the available } \\
\text { literature and reported on } \\
\text { information gathered from } \\
\text { Commonwealth government } \\
\text { agencies, State government } \\
\text { departments, youth refuges, } \\
\text { schools and non-government } \\
\text { organizations. }\end{array}$ & $\begin{array}{l}\text { There were } 100 \text { women } \\
\text { who were interviewed in } \\
\text { youth refuges, } 31 \text { were } \\
\text { incest survivors and } 18 \\
\text { mentioned some form of } \\
\text { sexual assault, } 79 \text { had } \\
\text { experienced physical or } \\
\text { emotional violence and } 69 \\
\text { of these mentioned the } \\
\text { father as the perpetrator. }\end{array}$ & $\begin{array}{l}\text { There are very few support } \\
\text { services for such young women } \\
\text { who are often left to cope by } \\
\text { themselves with problems of } \\
\text { guilt and alienation. }\end{array}$ \\
\hline $\begin{array}{lr}\text { Assaults } & \text { among } \\
\text { homeless } & \text { and } \\
\text { runaway adolescents. }\end{array}$ & 24 & $\begin{array}{l}\text { Outreach } \\
\text { counselors affiliated } \\
\text { with agencies that } \\
\text { worked } \\
\text { homeless }\end{array}$ & Survey & $\begin{array}{l}\text { Straus and Gelles's } \\
\text { measures of family violence. } \\
\text { Whitbeck and Simmons } \\
\text { measures of sexual abuse. } \\
\text { Whitbeck and Simon's }\end{array}$ & $\begin{array}{llr}\text { Results were } & \text { analyzed } \\
\text { using the } & \text { following } \\
\text { categories: } & \text { Parental } \\
\text { physical abuse, } & \text { Parental } \\
\text { sexual abuse, } & \text { deviant }\end{array}$ & $\begin{array}{l}\text { Adolescents' choice of survival } \\
\text { techniques affect their } \\
\text { vulnerability for serious } \\
\text { victimization. } \\
\text { women are at greater risk of }\end{array}$ \\
\hline
\end{tabular}


Citation: $\quad$ Xu L, Carpenter-Aeby T, Aeby VG, Lu W, Fisher L, et al. (2016) A Systematic Review of the Literature: Exploring Correlates of Sexual Assault and Homelessness. Trop Med Surg 4: 212. doi:10.4172/2329-9088.1000212

\begin{tabular}{|c|c|c|c|c|c|c|}
\hline & & $\begin{array}{l}\text { adolescents } \\
\text { contacted } \\
\text { participants. }\end{array}$ & & $\begin{array}{l}\text { measures of deviant peer } \\
\text { group. }\end{array}$ & $\begin{array}{l}\text { peers, length of time away } \\
\text { from home, deviant } \\
\text { subsistence strategies, } \\
\text { aggravated assault and } \\
\text { sexual assault. }\end{array}$ & $\begin{array}{l}\text { being sexually assaulted when } \\
\text { they affiliate with deviant peers. } \\
\text { Adolescent men are increased } \\
\text { risk for aggravated assault the } \\
\text { longer they stay away from } \\
\text { home. }\end{array}$ \\
\hline $\begin{array}{l}\text { Episodically } \\
\text { Homeless Women } \\
\text { with Serious Mental } \\
\text { Illness: Prevalence of } \\
\text { Physical and Sexual } \\
\text { Assault. }\end{array}$ & 25 & $\begin{array}{l}\text { Women who were } \\
\text { diagnosed with a } \\
\text { serious mental } \\
\text { illness were } \\
\text { interviewed between } \\
\text { August 1993 and } \\
\text { June 1994. All the } \\
\text { women had been } \\
\text { referred from a local } \\
\text { shelter or psychiatric } \\
\text { hospital. They were } \\
\text { either living on the } \\
\text { streets or in a } \\
\text { shelter. Most has } \\
\text { some form of } \\
\text { housing by the time } \\
\text { of the interviews. } \\
\text { There were a total of } \\
99 \quad \text { women } \\
\text { interviewed. }\end{array}$ & Qualitative & $\begin{array}{l}\text { Participant were paid } \$ 10 \text { for } \\
\text { the } 60-90 \text { minute interview. In } \\
\text { addition to data reported, the } \\
\text { interview protocol was } \\
\text { designed to illicit a wide } \\
\text { range of information on } \\
\text { backgrounds, prevalence of } \\
\text { physical and sexual assault } \\
\text { histories, and dimensions of } \\
\text { the violence experienced. }\end{array}$ & $\begin{array}{lcr}7 \% \text { reported minor } & \text { child } \\
\text { sexual } & \text { abuse, } & 58 \% \\
\text { reported severe } & \text { child } \\
\text { sexual abuse, } & 11 \% \\
\text { reported minor adult sexual } \\
\text { abuser } 65 \% \text { reported } \\
\text { severe adult sexual abuse. }\end{array}$ & $\begin{array}{l}\text { The findings of this study force } \\
\text { us to re-conceptualize the } \\
\text { notion of trauma, at least as it } \\
\text { occurs in the lives of highly } \\
\text { disenfranchised women. For } \\
\text { these women, the traumatic } \\
\text { events and experiences are so } \\
\text { inextricably woven into the } \\
\text { fabric of everyday life as to be } \\
\text { the normative. }\end{array}$ \\
\hline
\end{tabular}

Table 1: Literature review matrix for sexual assault and homelessness.

\begin{tabular}{|l|l|l|l|}
\hline Years & Keywords & Limiters & Number of Articles \\
\hline $1988-2015$ & Homelessness, sexual assault & Scholarly peer reviewed journals & $\mathrm{N}=104$ \\
\hline $1990-2015$ & Homelessness, sexual assault & Scholarly peer reviewed journals & $\mathrm{N}=42$ \\
\hline $2005-2015$ & Homelessness, sexual assault & $\mathrm{N}=25$ \\
\hline
\end{tabular}

Table 2: Synthesis of keywords.

\begin{tabular}{|c|c|c|c|c|}
\hline Author/Date & Type of Study & Purpose & General Comments & Strengths and Limitations \\
\hline Keeshin et al. [1] & $\begin{array}{l}\text { Empirical study, qualitative } \\
\text { study, interviews }\end{array}$ & $\begin{array}{l}\text { Identify the incidence of self- } \\
\text { reported physical and sexual } \\
\text { child abuse among homeless } \\
\text { youth. }\end{array}$ & $\begin{array}{l}\text { Abuse victims interested in } \\
\text { treatment options were more } \\
\text { likely to not have graduated } \\
\text { from high school. }\end{array}$ & $\begin{array}{l}\text { Project did not include formal qualitative } \\
\text { methodology. Small sample size. }\end{array}$ \\
\hline Maas et al. [2] & Qualitative & $\begin{array}{l}\text { Evaluating the needs of } \\
\text { unsupported homeless youth }\end{array}$ & $\begin{array}{l}\text { Women are reluctant to report } \\
\text { sexual abuse due to feeling } \\
\text { guilt, shame and fear. Young } \\
\text { people leave home to escape } \\
\text { rape and sexual abuse. }\end{array}$ & $\begin{array}{l}\text { This report is very detailed. There are } 10 \text { chapters } \\
\text { that discuss information on specific topics. } \\
\text { "Information about numbers of unsupported } \\
\text { students and their particular problems was very } \\
\text { sketchy."(p.16) }\end{array}$ \\
\hline Terrell [3] & Qualitative, Survey & $\begin{array}{l}\text { Examines aggravates and } \\
\text { sexual assaults among } \\
\text { runaway and homeless } \\
\text { adolescents in Des Moines, } \\
\text { lowa. }\end{array}$ & $\begin{array}{l}\text { One in eight adolescents will } \\
\text { run away from home prior to } \\
\text { his or her 18th birthday. }\end{array}$ & $\begin{array}{l}\text { Data collected from self-reports. Sample drawn } \\
\text { from one city, results cannot be generalized to } \\
\text { larger population. }\end{array}$ \\
\hline Tyler [4] & $\begin{array}{l}\text { Empirical study, quantitative } \\
\text { study }\end{array}$ & $\begin{array}{l}\text { Comparison of risk factors for } \\
\text { sexual victimization among } \\
\text { gay, lesbian, bisexual and } \\
\text { heterosexual homeless young } \\
\text { adults. }\end{array}$ & $\begin{array}{l}\text { Gay, lesbian and bisexual } \\
\text { homeless youth experience } \\
\text { more victimization compared } \\
\text { to heterosexual counterparts. }\end{array}$ & $\begin{array}{l}\text { Findings based on cross-sectional data- cause and } \\
\text { effect cannot be assumed. }\end{array}$ \\
\hline Holt et al. [5] & Qualitative & $\begin{array}{l}\text { Examines patterns of } \\
\text { traumatic abuse history in } \\
\text { women receiving mental } \\
\text { health treatment. }\end{array}$ & $\begin{array}{l}\text { High rate of lifetime exposure } \\
\text { to physical/sexual abuse } \\
\text { among homeless women. }\end{array}$ & $\begin{array}{l}\text { Small sample size } \\
\text { Underreporting of abuse history. }\end{array}$ \\
\hline
\end{tabular}


Citation: $\quad$ Xu L, Carpenter-Aeby T, Aeby VG, Lu W, Fisher L, et al. (2016) A Systematic Review of the Literature: Exploring Correlates of Sexual Assault and Homelessness. Trop Med Surg 4: 212. doi:10.4172/2329-9088.1000212

Page 10 of 12

\begin{tabular}{|c|c|c|c|c|}
\hline Heslin et al. [6] & Qualitative & $\begin{array}{l}\text { Examine community } \\
\text { characteristic and violence } \\
\text { against homeless women in } \\
\text { Los Angeles county }\end{array}$ & $\begin{array}{l}\text { Homeless people are at } \\
\text { higher risk for violent } \\
\text { victimization due to lack of } \\
\text { personal protective shelter. }\end{array}$ & $\begin{array}{l}\text { Community variables used zip codes of the } \\
\text { sampling site, not where victimization took place. }\end{array}$ \\
\hline Tsai et al. [7] & AB design Qualitative & $\begin{array}{l}\text { To examine correlations } \\
\text { between history of trauma and } \\
\text { housing. }\end{array}$ & $\begin{array}{l}\text { Different types of trauma } \\
\text { showed different patterns for } \\
\text { homelessness. Sexual } \\
\text { assault was associated with a } \\
\text { higher number of days spent } \\
\text { homeless. }\end{array}$ & $\begin{array}{l}\text { Substantial dropout rates during the study. Study } \\
\text { was based on self-reporting. }\end{array}$ \\
\hline Pavao et al. [8] & $\begin{array}{l}\text { Qualitative, National cross- } \\
\text { sectional study }\end{array}$ & $\begin{array}{l}\text { To estimate the prevalence of } \\
\text { military sexual trauma (MST) } \\
\text { and examine the correlation } \\
\text { between MST and mental } \\
\text { health conditions in homeless } \\
\text { populations. }\end{array}$ & $\begin{array}{l}\text { Veterans who experience } \\
\text { MST utilized significantly } \\
\text { more mental health visits } \\
\text { compared to those who did } \\
\text { not experience MST. }\end{array}$ & $\begin{array}{l}\text { Study only included veterans who use VHA- study } \\
\text { cannot be generalized to larger populations. }\end{array}$ \\
\hline $\begin{array}{l}\text { Goodman et al. } \\
\text { [9] }\end{array}$ & Qualitative, interview & $\begin{array}{l}\text { Evaluate the prevalence of } \\
\text { physical and sexual assault } \\
\text { on homeless women with } \\
\text { serious mental illness. }\end{array}$ & $\begin{array}{l}\text { Results indicate that lifetime } \\
\text { risk for victimization was so } \\
\text { high that it was considered a } \\
\text { normal experience for this } \\
\text { population. }\end{array}$ & $\begin{array}{l}\text { Reliability of participants' reports due to severe } \\
\text { mental illness. Study was mostly urban, African } \\
\text { American women who also suffered from } \\
\text { substance abuse, generalizability is an issue. }\end{array}$ \\
\hline $\begin{array}{l}\text { Washington et al. } \\
\text { [10] }\end{array}$ & $\begin{array}{l}\text { Qualitative, case control } \\
\text { study }\end{array}$ & 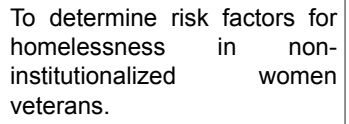 & $\begin{array}{l}\text { Sexual assault is a } \\
\text { characteristic associated to } \\
\text { homelessness. }\end{array}$ & $\begin{array}{l}\text { Large sample size. Limited in ability to establish a } \\
\text { complete sampling frame due to the transitory } \\
\text { nature of the participants. }\end{array}$ \\
\hline Rew [11] & $\begin{array}{l}\text { Qualitative, } \quad \text { survey, } \\
\text { interviews }\end{array}$ & $\begin{array}{l}\text { Evaluate the relationship of } \\
\text { sexual abuse and perceived } \\
\text { well-being among homeless } \\
\text { youth. }\end{array}$ & $\begin{array}{l}\text { Sexual abuse rates are higher } \\
\text { among homeless youth when } \\
\text { compared to non-homeless. } \\
\text { Significant relationship among } \\
\text { sexual abuse and perceived } \\
\text { well-being. }\end{array}$ & Convenience sampling utilized. \\
\hline $\begin{array}{l}\text { Whitbeck et al. } \\
\text { [12] }\end{array}$ & $\begin{array}{l}\text { Qualitative, longitudinal } \\
\text { diagnostic study }\end{array}$ & $\begin{array}{l}\text { Examine victimization and } \\
\text { PTSD among run away and } \\
\text { homeless adolescents }\end{array}$ & $\begin{array}{lcr}\text { Lives of runaway } & \text { and } \\
\text { homeless } & \text { youth } & \text { are } \\
\text { characterized } & \text { by } & \text { high } \\
\text { frequency } & \text { of } & \text { rape. } \\
\text { Molestation and } & \text { other } \\
\text { traumatic events. }\end{array}$ & $\begin{array}{l}\text { Nonprobability sample. Finding are limited to } \\
\text { adolescent self-report and not parent reports. }\end{array}$ \\
\hline Tyler \& Beal [13] & Qualitative & $\begin{array}{l}\text { Investigate the potential risk } \\
\text { for victimization among } \\
\text { homeless young adults. }\end{array}$ & $\begin{array}{l}\text { Between one-third and one- } \\
\text { half of homeless youth have } \\
\text { experienced sexual or } \\
\text { physical victimization since } \\
\text { being on the street. }\end{array}$ & $\begin{array}{l}\text { All data was based on self-reports. Reports were } \\
\text { retrospective in nature which may have affected } \\
\text { the accuracy of the reports. }\end{array}$ \\
\hline Sundin et al. [14] & Systematic Review & $\begin{array}{l}\text { Study the prevalence of } \\
\text { childhood abuse among } \\
\text { people who are homeless in } \\
\text { Western Countries. }\end{array}$ & $\begin{array}{l}\text { Findings suggest that } \\
\text { childhood physical and sexual } \\
\text { abuse is more prevalence } \\
\text { among homeless populations } \\
\text { in Western countries than in } \\
\text { the global population. }\end{array}$ & $\begin{array}{l}\text { Convenience sampling led to slightly higher } \\
\text { estimates of sexual abuse. }\end{array}$ \\
\hline $\begin{array}{l}\text { Tyler \& Melander } \\
\text { [15] }\end{array}$ & Cross- sectional & $\begin{array}{l}\text { Investigate risk factors for } \\
\text { discrepant reporting of } \\
\text { physical and sexual abuse } \\
\text { among homeless young } \\
\text { adults. }\end{array}$ & $\begin{array}{l}\text { Males are more likely to } \\
\text { initially deny abuse. Minorities } \\
\text { are more likely to be } \\
\text { discrepant reporters due to } \\
\text { perceived lack of resources. }\end{array}$ & $\begin{array}{l}\text { Data is based off self-reporting. Reporting is } \\
\text { retrospective which may result in over or under } \\
\text { reporting. }\end{array}$ \\
\hline $\begin{array}{l}\text { Davies-Netzley } \\
\text { et al. [16] }\end{array}$ & Qualitative, interview & $\begin{array}{l}\text { To determine if childhood } \\
\text { abuse is a precursor to } \\
\text { homelessness. }\end{array}$ & $\begin{array}{l}76.7 \% \text { of participants reported } \\
\text { experiencing abuse during } \\
\text { childhood. }\end{array}$ & $\begin{array}{l}\text { Participants were taking part in a larger study } \\
\text { related to independent housing. }\end{array}$ \\
\hline $\begin{array}{l}\text { Powers et al. } \\
{[17]}\end{array}$ & Qualitative & $\begin{array}{l}\text { Demonstrate a demographic } \\
\text { profile of maltreatment. }\end{array}$ & $\begin{array}{l}\text { Maltreatment usually remains } \\
\text { hidden. Research has proven } \\
\text { that abuse and neglect were } \\
\text { the causes of the youth } \\
\text { population running away and } \\
\text { becoming homeless. }\end{array}$ & $\begin{array}{l}\text { Cannot specify whether behaviour are more } \\
\text { prevalent among runaway and homeless youth } \\
\text { than among all troubled youth. }\end{array}$ \\
\hline
\end{tabular}




\begin{tabular}{|c|c|c|c|c|}
\hline Ferguson [18] & Cross-sectional study & $\begin{array}{l}\text { Explore the psychosocial and } \\
\text { behavioral adjustment } \\
\text { outcomes of multi-type abuse } \\
\text { among homeless young } \\
\text { adults. }\end{array}$ & $\begin{array}{l}\text { Homeless young people are } \\
\text { highly likely to come from } \\
\text { multi-problem and abusive } \\
\text { families. }\end{array}$ & $\begin{array}{l}\text { Sample is not likely representative of larger sample } \\
\text { of homeless young adult population. Abuse } \\
\text { assessments were conducted by self-reporting. }\end{array}$ \\
\hline $\begin{array}{l}\text { Johnson et al. } \\
\text { [19] }\end{array}$ & Secondary analysis & $\begin{array}{l}\text { Examine gender differences } \\
\text { among victimized homeless } \\
\text { adolescents. }\end{array}$ & $\begin{array}{l}\text { Experience of sexual abuse, } \\
\text { particularly in females, has } \\
\text { long term health effects. } \\
\text { Female victims are more } \\
\text { likely to run away from home } \\
\text { than males. }\end{array}$ & $\begin{array}{l}\text { Study was conducted in only one city and therefore } \\
\text { cannot be generalized. Self -reporting instruments } \\
\text { were utilized. }\end{array}$ \\
\hline $\begin{array}{l}\text { Whitbeck et al. } \\
{[20]}\end{array}$ & Qualitative & $\begin{array}{l}\text { Examine the prevalence of } \\
\text { traumatic events among } \\
\text { homeless women. }\end{array}$ & $\begin{array}{l}\text { Examine the prevalence of } \\
\text { traumatic events among } \\
\text { homeless women. }\end{array}$ & $\begin{array}{l}\text { Examine the prevalence of traumatic events } \\
\text { among homeless women. }\end{array}$ \\
\hline $\begin{array}{l}\text { Hudson et al. } \\
\text { [21] }\end{array}$ & Qualitative & $\begin{array}{l}\text { To examine correlations } \\
\text { between adult assault and } \\
\text { homeless women. }\end{array}$ & $\begin{array}{l}\text { Among homeless women, } \\
\text { approximately one third of } \\
\text { respondents reported a } \\
\text { history of childhood physical } \\
\text { or sexual abuse. }\end{array}$ & $\begin{array}{l}\text { Participants only included homeless women from } \\
\text { participating shelters in the Los Angeles area or } \\
\text { lived on the street. Study may not be generalized. }\end{array}$ \\
\hline Decker et al. [22] & Observational Study & $\begin{array}{l}\text { Examine the correlation } \\
\text { between Military Sexual } \\
\text { Assault and Homeless } \\
\text { Women Veterans }\end{array}$ & $\begin{array}{llr}\text { Examine the correlation } \\
\text { between Military } & \text { Sexual } \\
\text { Assault and Homeless } \\
\text { Women Veterans }\end{array}$ & $\begin{array}{l}\text { Absence of comparison sample. All data was self- } \\
\text { reported. Lack of details of specific behavior and } \\
\text { childhood abuse. }\end{array}$ \\
\hline Pluck et al. [23] & Qualitative & $\begin{array}{l}\text { Describe levels of traumatic } \\
\text { childhood events in a sample } \\
\text { of homeless individuals }\end{array}$ & $\begin{array}{lrr}\text { Homeless } & \text { populations } & \text { often } \\
\text { display high levels of } & \text { leveric } \\
\text { alcoholism, } & \text { psychotic } \\
\text { disorders } & \text { and } & \text { major } \\
\text { depression } & \text { and } & \text { personality } \\
\text { disorders. } & & \end{array}$ & $\begin{array}{l}\text { Data collected retrospectively which may results in } \\
\text { over or under reporting. }\end{array}$ \\
\hline $\begin{array}{l}\text { Chambers et al. } \\
\text { [24] }\end{array}$ & Cross-sectional study & $\begin{array}{l}\text { Estimate the prevalence of } \\
\text { mental health problems } \\
\text { among homeless women with } \\
\text { or without a dependent. }\end{array}$ & $\begin{array}{l}\text { Homeless women both with } \\
\text { and without a dependent have } \\
\text { poor mental health status. }\end{array}$ & $\begin{array}{l}\text { Since study was cross-sectional- unable to } \\
\text { attribute causation. Did not recruit women from } \\
\text { violence shelters therefore study may } \\
\text { underestimate true prevalence. }\end{array}$ \\
\hline Yeater et al. [25] & Empirical study, quantitative & $\begin{array}{l}\text { Examine whether drinking to } \\
\text { cope mediates the } \\
\text { relationship between PTSD } \\
\text { symptoms and current alcohol } \\
\text { use in homeless, ethnically } \\
\text { diverse women. }\end{array}$ & $\begin{array}{l}\text { Results suggest that women } \\
\text { may be "self-medicating" to } \\
\text { ameliorate trauma symptoms. }\end{array}$ & $\begin{array}{l}\text { Sample size was small, making it impractical to } \\
\text { test differences between ethnic groups. }\end{array}$ \\
\hline
\end{tabular}

Table 3: synthesis of key articles for homelessness, sexual assault, scholarly peer reviewed articles (1988-2015).

Three studies conducted on homeless veterans were located among databases concerning the relationship of homelessness to military sexual assault. A key study linking homelessness to sexual assault used female veterans as its study population [10]. Decker et al. found that $41-53 \%$ of homeless female veterans reported being victimized in sexual assault, and women who have served in the military are three to four times more likely become homeless than non-veteran women [22]. Due to such trauma, many of the female veterans acknowledged psychiatric symptoms and greater severity of PTSD, mood disorders, insomnia, nightmares, anxiety, and misuse of drugs to cope with the abuse described. Pavao et al. uncovered that military veterans using the VHA that had experienced sexual trauma while serving had undergone more mental health visits than those who did not [8].

There has also been research on between homelessness and the presence of mental illness in the general population, of which six studies were compiled. Pluck et al. found that homeless populations have high levels of mental disorders, including alcohol abuse, depression, personality disorders, and psychosis [23]. In one study performed by Chambers et al. in Toronto, Canada, 522 women were recruited from shelters and meal programs, who were either with or without dependent children [24]. The study concluded that poor mental health status was associated with homeless women whether they had dependent children or not. Over one-half of this sample was considered to have either a mental health or substance use problem in the past 12 months. Yeater et al. also obtained findings that homeless women with psychological disorders self-medicate through use of illicit drugs or alcohol [25]. Both directionalities of homelessness with a mental disorder and sexual abuse each had an existing study. Of the findings of mentally ill homeless people, Goodman et al. indicated that sexual abuse among a sample of those who were both homeless and mentally ill was the norm [9]. High rate of life-time sexual abuse was also found to be indicative of long term effects on mental and physical health in a population of homeless adolescents by Johnson et al. [19].

\section{Discussion}

With only 25 articles uncovered related to this topic, there is a paucity of information centered on numerous issues. Such limitations of the sample populations used included location, demographic areas, 
self-reporting, race, small sample sizes, and the reliability of participants' report, particularly those with mental illnesses. Some studies relied only on zip codes of the sampling site, rather than where the victimization took place [6]. A large portion of the surveys used women as the only source of data, limiting the information about male sexual assault homeless victims. This may be attributed to individual study concern or resultant of the finding that men are less likely to report their abuse history [15]. With three articles remotely broaching this subject, a limited amount of research has been recorded with regards to the correlation between homelessness and military victims of sexual assault due to self-reporting. In women with mental health illnesses, there was underreporting of their abuse history. Above all, no information exists on the relationship between sexual assault and the likelihood of recovering from homelessness. As it stands, the information on this particular concern of the demographic is not comprehensive or reliable enough to accurately assess this population's needs.

Studies on the topic of homelessness and sexual assault have been conducted for the past few decades, and the existing results provide a wide variety for implications to help improve social work practice and policy. These implications vary depending on the specific population that is being studied. The most popular implications were education, training and improving interventions.

The first concern exists with improving the options for homeless people to deal with their trauma and disorders for the present. It is imperative that such victims are informed of and referred to health services within their community, who will provide care and treatment for the homeless at no charge. Programs are needed to provide homeless female veteran accommodations that will assist with genderspecific concerns. However, most shelters do not have adequate housing for the number of female veterans who need accommodation, and the general institution of homeless shelters has been deemed inadequate as recent as within the past decade $[6,8]$. Due to the nature of sexual assault within military populations, trauma-informed approaches are important in caring for homeless veterans [23].

Numerous amounts of youth on the streets who have undergone many encounters of physical and sexual assault/abuse since being on their own. Community awareness facilities would be beneficial to the youth on the streets that could offer counseling, self-esteem awareness classes and group therapy. Due to the long lasting effects of childhood abuse and trauma, adolescents may lack trust and self-confidence needed to recover from their psychological damage [20]. Such activities and safe places could decrease the amounts of sexual assault and abuse, thus decreasing risky and dangerous behaviors they would normally be involved with. Training programs are needed to work on self-confidence as well as trade and workplace skills.

\section{References}

1. Keeshin BR, Campbell K (2011) Screening homeless youth for histories of abuse: prevalence, enduring effects, and interest in treatment. Child Abuse Negl 35: 401-407.

2. Maas F, Hartley R (1988) On the Outside: The needs of Unsupported, Homeless Youth. Australian Institute of Family Studies 304: 1-102.

3. Terrell N (1997) Street life: aggravated and sexual assaults among homeless and runaway adolescents. Youth \& Society 28: 267-290.

4. Tyler KA (2008) A comparison of risk factors for sexual victimization among gay, lesbian, bisexual, and heterosexual homeless young adults. Violence Vict 23: 586-602.
5. Holt RL, Montesinos S, Christensen RC (2007) Physical and sexual abuse history in women seeking treatment at a psychiatric clinic for the homeless. J Psychiatr Pract 13: 58-60.

6. Heslin KC, Robinson PL, Baker RS, Gelberg L (2007) Community characteristics and violence against homeless women in Los Angeles County. J Health Care Poor Underserved 18: 203-218.

7. Tsai J, Rosenheck RA, Decker SE, Desai RA, Harpaz-Rotem I (2012) Trauma experience among homeless female veterans: Correlates and impact on housing, clinical, and psychosocial outcomes. J Trauma Stress 25: 624-632.

8. Pavao J, Turchik JA, Hyun JK, Karpenko J, Saweikis M, et al. (2013) Military sexual trauma among homeless veterans. J Gen Intern Med 28 Suppl 2: S536-541.

9. Goodman LA, Dutton M, Harris M (1995) Episodically Homeless Women with Serious Mental Illness: Prevalence of Physical and Sexual Assault. Am J Orthopsychiatry 65: 468-478.

10. Washington DL, Yano EM, McGuire J, Hines V, Lee M, et al. (2010) Risk factors for homelessness among women veterans. J Health Care Poor Underserved 21: 81-91.

11. Rew L (2002) Relationships of sexual abuse, connectedness, and loneliness to perceived well-being in homeless youth. Journal for Specialist in Pediatric Nursing 7: 51-63.

12. Whitbeck LB, Hoyt DR, Johnson KD, Chen X (2007) Victimization and posttraumatic stress disorder among runaway and homeless adolescents. Violence Vict 22: 721-734.

13. Tyler KA, Beal MR (2010) The high-risk environment of homeless young adults: consequences for physical and sexual victimization. Violence Vict 25: 101-115.

14. Sundin EC, Baguley T (2015) Prevalence of childhood abuse among people who are homeless in Western countries: A systematic review and meta-analysis. Soc Psychiatry Psychiatr Epidemiol 50: 183-194.

15. Tyler KA, Melander LA (2009) Discrepancies in reporting of physical and sexual abuse among homeless young adults. J Child Sex Abus 18: 513-531.

16. Davies-Netzley S, Hurlburt MS, Hough RL (1996) Childhood abuse as a precursor to homelessness for homeless women with severe mental illness. Violence Vict 11: 129-142.

17. Powers JL, Eckenrode J, Jaklitsch B (1990) Maltreatment among runaway and homeless youth. Child Abuse Negl 14: 87-98.

18. Ferguson KM (2009) Exploring the psychosocial and behavioral adjustment outcomes of multi-type abuse among homeless young adults. Social Work Research 33: 219-230.

19. Johnson RJ, Rew L, Kouzekanani K (2006) Gender differences in victimized homeless adolescents. Adolescence 41: 39-53.

20. Whitbeck LB, Armenta BE, Gentzler KC (2015) Homelessness-Related Traumatic Events and PTSD Among Women Experiencing Episodes of Homelessness in Three U.S. Cities. J Trauma Stress 28: 355-360.

21. Hudson AL, Wright $\mathrm{K}$, Bhattacharya D, Sinha K, Nyamathi A, et al. (2010) Correlates of adult assault among homeless women. J Health Care Poor Underserved 21: 1250-1262.

22. Decker SE, Rosenheck RA, Tsai J, Hoff R, Harpaz-Rotem I (2013) Military sexual assault and homeless women veterans: Clinical correlates and treatment preferences. Women's Health Issues 23: 373-380.

23. Pluck G, Lee K, David R, Macleod DC, Spence SA, et al. (2011) Neurobehavioral and cognitive function is linked to childhood trauma in homeless adults. Br J Clin Psychol 50: 33-45.

24. Chambers C, Chiu S, Scott AN, Tolomiczenko G, Redelmeier DA, et al. (2014) Factors associated with poor mental health status among homeless women with and without dependent children. Community Ment Health J 50: 553-559.

25. Yeater EA, Austin JL, Green MJ, Smith JE (2010) Coping mediates the relationship between posttraumatic stress disorder (PTSD) symptoms and alcohol use in homeless, ethnically diverse women: A preliminary study. Psychological Trauma: Theory, Research, Practice, and Policy 2: 307-310. 